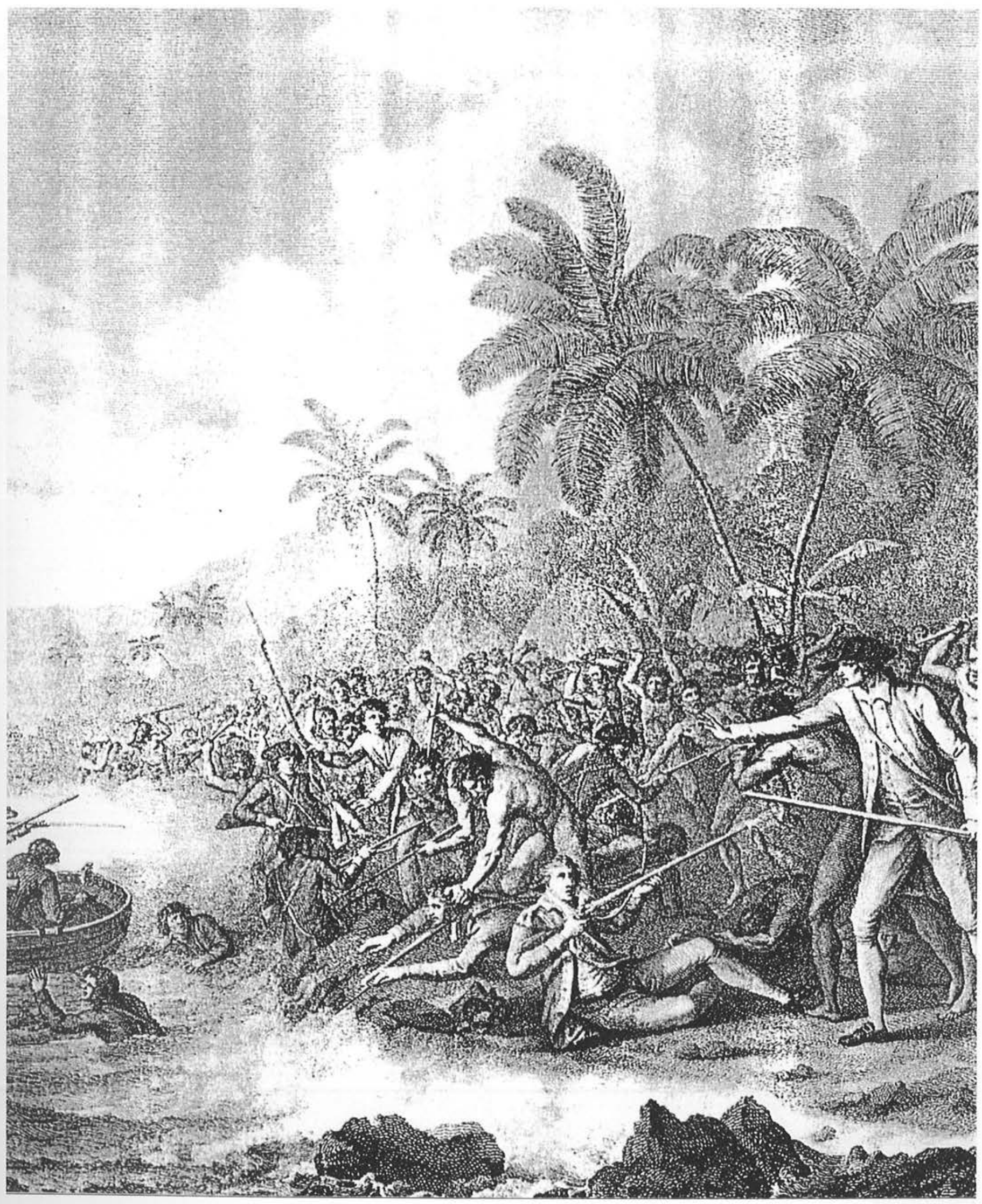


Coconuts:

\title{
First Persons Singular and Un-relative Events
}

\author{
"Into our bay one morning sailed a fleet of ships flying the British flag and anchored offshore. The gunwales and \\ rigging were full of sailors carrying pineapples and tortoises and waving scrolls with maxims on them in Latin and \\ English. On the quarter-deck, amid officers in tricorne and wig, Captain Cook fixed the shore with his telescope."
}

(Italo Calvino, The Cloven Viscount)

It is perhaps not necessary to point out that this scene never occurred except in the imagination of a novelist, for rarely in the history of voyages is a potential discoveree likely to be treated to such an elaborate pantomime of authenticity. In the fiction, each exotic thing held up by the sailors is matched and naturalised by an inscription. The particular article - a pineapple, a tortoise - is no sooner displayed than it is fetched within the frame of knowledge and made exemplary of some maxim or truth. The scrolls of Latin and English wisdom redeem the scene from all troublesome strangeness by rendering it legible, and by transforming the enigma of discovery into a recognisable event and a valuable lesson. It meets the condition laid down by Jeremy Bentham for making voyages of discovery run parallel with good instructions: "If it be a matter of importance and of use to us to be made acquainted with distant countries, surely it is not a matter of much less importance, nor of much less use to us, to be made better and better acquainted with the chief means of living happily in our own."1

If the scrolled plunder from remote places brings the event of Captain Cook's voyages ethically and topographically home to the people on the shore in Calvino's story, it does so by means of a dialectic of the particular and the universal that authorises the equation, on the one hand, between the unspeakably singular thing and an untruth and, on the other, between language and universality. No matter how particular you may mean a thing to be, to speak at all is to exhibit the divine capacity of language of reversing the meaning of what is said in respect of sense-certainty. Should the sailors on the gunwales and the rigging be supposed to be engaged with their pineapples and tortoises in a mime of sense-certainty, pointing at 'absolutely singular entities,' unique sensuous objects pinpointed as 'this' tortoise and 'this' pineapple, then either what is meant cannot be reached by language insofar as they are trying to speak (like Gulliver when he talks of European peculiarities in Houyhnhmland) about an irrational idea, 'something which is not'; or they succeed in saying something quite contrary from what they intend: to impersonate Hegel: "When I say, 'a single thing,' I am really saying what it is from a wholly universal point of view, for everything is a single thing; and likewise 'this thing' is anything you like... and I have only uttered the universal all the time." 2 The inscribed scrolls are icons of the power of language to retrieve as significant the most heterogeneous particulars of a voyage of discovery. Without the script you have, from a public point of view, nothing. Speaking of the difficulties encountered by the first chroniclers of the Spanish conquest and settlement of America, Anthony Pagden points out that all particulars falling outside of the canon were simply nonsense: "Nothing could be made intelligible in terms of an alternative non-scriptural authority." 3 Without a scroll, historians of the Conquista, such as Oviedo and Las Casas, are condemned to the perpetual repetition of the same vain gesture of specification ("the wild animals, the tigers, lions, serpents and other noxious beings" - Oviedo) with nothing but the first person singular to authenticate it ("Only I can be trusted to know what I write" - Las Casas). (Pagden, pp. 61, 76)

I want to see if the same dialectic that universalises the particular tortoise and pineapple holds in respect of a coconut. On the day that Cook died he was in pursuit of some particular things tongs, chisels, the lid of a water-cask and the Discovery's cutter - that had gone missing the day before. He took hostage the senior local chief, Kalani'opu'u, usually a successful tactic in obtaining the return of pilfered equipment. While the crowd was assembling that was shortly to disperse the British and to kill Cook, Kalani'opu'u was crouched by the ships' boats, detained by two of his chiefs and his wife, Kaneikapolei, apparently very unwilling to go on board. At this critical juncture a priest chose to offer the dejected chief and the angry captain a coconut. According to an eye-witness, Lt Molesworth 
Phillips, it was all a ruse: "An artful Rascal of a Priest was singing and making a ceremonious offering of a Coco Nut to the Captain and Terre'oboo to divert their attention from the Manoeuvres of the surrounding multitude." 4

Probably the finest account of this translation, and the one that is most faithful to the structure of the dialectic, is that of Marshall Sahlins. According to him the fruit is placed at the site of a conflict of the human and divine, signalling the imminence of a sudden shift of power relations that is typical of the usurpational pattern of Hawaiian cultural history. This crisis by the boats is one of the many radical contingencies that disturb but also renew a culture capable, under the stress of the unforeseen accidents and chances, of improvising a functional revaluation of mythic signifiers and absorbing the interruptive phenomenon - including "this unparalleled Commander" Captain Cook ${ }^{5}$ - into its mode of reproduction. If Hegel triumphantly exhibits the paradox of a singular entity that declares the universal, Sahlins is no less delighted by antinomies which proclaim the continuity of interruptions. In the case of Cook's arrival at Kealakekua Bay, "The event was absolutely unique, and it was repeated every year." 6 The scene by the boats for an instant destabilises the triad of 'the god, the man, and the woman' upon which the ritual of the Makahiki is founded; but inscribed on the scroll beneath Sahlins' coconut is this maxim, "Usurpation itself is the principle of legitimacy." (Sahlins, p. 80)

Challenging what he takes to be the Eurocentric and hagiographic assumptions behind Sahlins' theory of conjuncture, Gananath Obeyesekere tries to locate the coconut within the practical rationality of an Hawaiian discourse notable for "contentious and multiple interpretation," one capable of weighing "the actuality of myth and event against the pragmatics of commonsense." $7 \mathrm{He}$ concedes, however, that the pre-European culture of Hawaii is hard to find behind the interpretative crust left behind by explorers, missionaries and structural anthropologists. Indigenous history has been so far corrupted by rival systems of language and belief that all Obeyesekere can reasonably be sure of is that Hawaiians must have known the difference between a god and a man (Lono and Cook), and between the miniature boat in which the god is represented as travelling and Cook's vessel, the Resolution. His privileging of an empiricist practice leaves him scant room for manoeuvre, however, when it comes to the coconut. He is refusing Sahlins' dialectic, on the one hand, but, on the other, has insufficient access to cultural data to estimate the ritual value of the priest's gesture and chant. "My own guess is that we will never know why this offering was made jointly to Cook and Kalani'opu'u, and any number of hypotheses are possible and plausible."(Obeyesekere, p. 180) While keeping in reserve the possibility of an explanation, Obeyesekere allows the coconut to float free of scrolls and to claim a particularity independent of a local or universal meaning. Instead of registering the repeatability of a unique event, the coconut remains obstinately a coconut, signing and representing nothing, simply constituting an unimprovable contingency: a bare chance, a sheer whim, an event unconnected with any of the other particulars of that day: the tongs, the chisels, the lid of the watercask, etc., which erupt into the story of Cook's death with the same weird irrelevance.

Everyone involved in this disjointed episode was agreed upon its unaccountability. It was a "sudden and confused transaction," an "accidental affray," "a chain of events which could no more be foreseen than prevented." 8 There were no scrolls to make these particulars intelligible, and therefore no adequate account or narrative to mitigate what William Dampier calls "the Hazard of all outward Accidents in strange and unknown Seas." "It is very hard to be sure of anything of this sort," observes John Harris of reports from the Southern Ocean. ${ }^{10}$ Let us consider what is at stake in the representation of hazards and uncorroborated circumstances. There is the thing itself - the coconut and the first person singular who saw it; then there is the testimony of the first person and the audience who will receive or reject it. The aim of the narrator is to convey the unprecedented and unexampled impact of the experience; the aim of the audience is to test its credibility and to understand it. These aims are not compatible; for if the experience is probable and intelligible - that is, if it will bear a scroll above it - it is less than novel and will have failed to render the utter particularity of the thing itself; but if it succeeds in conveying the flavour of the encounter with the bare hazard and the loose circumstance, it will cost the narrator the belief of the audience who, while eager to hear of wonders, will accommodate nothing that is not authorised by an antecedent idea. William Wales, astronomer on Cook's second voyage, puts it like this: 
a stupid fellow to have gone so far and brought home so little; and if he does, why - it is hum - aya - a tap of the Chin; and - He's a Traveller. (MS 315, Smith 138)

The uncommon is not necessarily intrinsically incredible, as is the miraculous or the marvellous; it becomes so only when the degree of connection between one particular and another falls below the level of probability required by circumstantial evidence. 11 Cook found tattooing as troublesome as cannibalism on his first voyage because he could not assign a cause for it. "The manner in which it is done must certainly cause intolerable pain and may the reason why so few are mark'd at all, at least I know no other."(1.279) Like the Maori design admired for its extravagance by Banks, such a phenomenon is self-subsistent, comparable to itself alone, "and I may truly say like nothing but itself." $(2.14,24)$ As Michel de Certeau observes, "the history of voyages... tolerates or privileges as an 'event' that which makes an exception to the interpretative codes."12 The result of operating outside these genres and codes is that even the slightest particulars, when lacking connection with other circumstances and ideas, acquire the same implausibility in the reader's eyes as the monstrous; and in insisting upon them, the voyager is reduced to an iterative or tautologous style that always signals what systems theorists call the improbability of a highly personal message. Forsaking all validating norms, and resting on nothing more solid than the affirmations and figures ornamenting the autoptic claim, 'I saw it with my own eyes,' the natural destination of such a message is complaint, the most improbable of all personal communications. Therefore, we are likely to hear complaints against painful contingencies and against their unintelligibility, complaints against the reader who disbelieves what has been equally difficult to experience and to articulate. Pagden notices this tendency in the historians of the Conquista. "In Oviedo's text, complaints about the conditions of composition rapidly slide into complaints about the conditions of life ... the narrator fashions himself as a sufferer."(Pagden, p. 66) Ovieda starts quoting Job.(p. 61, n.37)

It is not just the monstrous, then, that the reader resists, but any event which stands beyond the bounds of knowledge. The reader objects also to the prose in which the event is delivered, whose fault is not that it is hyperbolic or extravagant, but that it is circumstantial in a self-evident and circular way, and that it is couched in an idiom which emphasises the singularity of the first person who has endured the hazard. David Hume, in his essay "Of Miracles," mentions "the miraculous accounts of travellers... their descriptions of sea and land monsters, their relations of wonderful adventures, strange men, and uncouth manners" in a context of the miracle as an event divorced from general experience, "when the fact attested is such a one as has seldom fallen under our observation."13 A miracle is no more than a chance that cannot be familiarised by previous experience or authority: an impression lacking the antecedent idea that would warrant its telling. It is like the bare print of a single foot that terrifies Robinson Crusoe, and would terrify anyone limited to the exiguous inference which Hume allows to be the only one that can legitimately be drawn from it, namely "that there was some figure adapted to it, by which it was produced." 14 The slightest circumstance of a narrative that does not encourage the mind comfortably to ascent "from the effect to the cause; and descending again from the cause, infer alterations in the effect"(Hume, Enquiry, p.144), will be construed as miraculous and monstrous. Sailors' stories are disbelieved because great hazards are bare chances, and "of so singular and particular a nature as to have no parallel and no similarity with any other cause or object." (Hume, Enquiry, p.148) The hagiography of Cook deprecated by Obeyesekere germinates in the unforeseeable chances and uninterpretable particulars of his death, including the coconut which imparts a miraculous flavour to the event in proportion as it divides it from the universal that would assign it a cause, and inscribe it on a scroll. The coconut is the monstrous first step in the insistence upon that absolutely singular entity which (according to Hegel) is the thing which is not, and which must therefore be a lie. It is the irreducible detail for which no place has been assigned in the order of things and in the genres of narrative.

In fact, Hume questions whether it is possible for an entirely singular and unparalleled event to have a place in our consciousness; but Lord Bolingbroke, starting from a position similar to Hume's, argues that there are such things as coconuts in history:

The events we are witnesses of, in the course of the longest life, appear to us very often original, unprepared, single, and un-relative, if I may use such an expression for want of a better in English ... they appear such very often, are called accidents, and looked on as the effects of chance ... We get over the present difficulty, we improve the momentary 
advantage, as well as we can, and we look no further. Experience can carry us no further; for experience can go a very little way back in discovering causes: and effects are not the objects of experience till they happen. ${ }^{15}$

Aestheticising this historical problem, Diderot compares the loneliness of the imaginative dramatist with the traveller at the edge of the world: "he is sometimes uncertain if the thing that he declares to there is a reality or a chimera, or if it has any existence outside of himself. He is then at the furthest limits of the energy of the nature of man, and at the extremity of the resources of art."(Pagden 165; Oeuvres Aesthetique , 213)

If we look at one of Cook's examples of an un-relative event, experienced at the limit, you can see why the experience delights him and why the report troubles him. He is explaining how the wall of ice he met in the Antarctic put an end to his search for the great southern continent, the task set him by the Admiralty in his first two voyages.

\begin{abstract}
I, whose ambition leads me not only farther than any other man has been before me, but as far as I think it is possible for man to go, was not sorry at meeting with this interruption, as it in some measure relieved us from the dangers and hardships, inseparable with the Navigation of the Southern Polar regions. Since therefore we could not proceed one Inch farther South, no other reason need be assigned for our Tacking and stretching back to the North ... I will not say it was impossible any where to get farther to the South, but the attempting of it would have been a rash and dangerous enterprise and what I believe no man in my situation would have thought of. ${ }^{16}$
\end{abstract}

The strained egoism of the entry is owing to the straddling of two irreconcilable extremes demanded of the first person at the limit of the known world. On the one side Cook claims a superbian interest in the uniqueness of his experience, which he has scarcely any need to explain or justify because it is unprecedented and unscrollable; on the other, he is aware of a public that will refuse to locate the limit within the purview of the first person singular, and will want to know why it was found there and not further southward. If there is anything that compensates him for the pains of navigating unknown seas it is Cook's strong sense of being the first person in them, the ' $\mathrm{I}$ ' possessed of a singular view of a marvellous thing. But if it is expressive of the absence of what ought to be there, and for which a place has been assigned in the narrative formed out of his Admiralty instruction and the inventories of naval stores, Cook becomes very anxious indeed. ${ }^{17}$ The tongs, chisels and the lid of the water-cask bear comparison in this respect with the Great Southern Continent, insofar as they are items forming the circumstantial whole of an Admiralty document that constitutes Cook's notion of scrolls. A piece of equipment that goes missing, or a continent that fails to be found, makes a breach in the orderly summary of things and events that his public - the Lords of the Admiralty - have prescribed and require of him.

Hence the troubled sublimity of his meeting with the ice. "I, whose ambition leads me... as far as it is possible to go." What ought to have been the self-proclaimed triumph of the 'I' breaks down into an appeal to a third person standard of probability - the hypothesised 'man in my situation' who takes the place of an antecedent idea, and who imports the question of probability into an account of a particular and un-relative event. As soon as the first person makes room for this other possibility, the incontrovertibility of firstness that it commands crumbles, like the ice, into an alternative (the other man, the unseen gap) which transforms the limit into a predictable index of personal shortcoming, a failure of subjective agency the very opposite of what the first person wants to claim. The sublime of exploration is bordered by the guilt which turns overreaching into diffidence, and supererogatory effort into unworthy caution.

This is anomie in the strict sense of the term: a discrepancy between the norms of success and the institutional means provided for its attainment. ${ }^{18}$ Cook experiences it whenever he crosses the border that divides specific instruction from improvisation in the face of the hazard. His Letters of Instruction partly explain why, because they try to incorporate bare chances within the intelligible system of written orders. They told him, "But for as much as in an undertaking of this nature several Emergencies may Arise not to be foreseen, and therefore not particularly to be provided for by Instruction before hand, you are in all such Cases, to proceed, as upon advice with your Officers you shall judge most advantageous to the Service on which you are employed."(Beaglehole, 1. cclxxxiii) Here, the independence of the un-relative event is pre-empted by the same paradox that establishes 
the standard of taste in eighteenth-century aesthetic theory. Although what will occur will subjectively be absolutely singular, it will nevertheless be reported as if it were obedient to a law, or some a priori concept. However, from the side of the first person singular, the un-relative event corresponds much more closely to the case of the sublime, insofar as the measure of subjective intensity is the presentation of the unpresentable: specifically the impossibility of representing the discovery of the absence of a continent in an accessible and probable manner to the public.

Cook is aware that his is an impossible task of presentation, and in two remarkable entries in the Endeavour journal he tries to isolate the difficulty of narrating a limit-event. The first concerns the limit itself, which confusingly manifests itself to the voyager as confirmation that the outermost boundary has been breached, and also as the obstruction to the possibility of further exploration. It combines features of the pure hazard and with the predictable (and therefore removable) impediment. The second tackles probability in respect of the exaggeration in sailors' stories and the difficulty of believing them.

Such are the Vicissitudes attending this kind of service and must always attend an unknown Navigation: Was it not for the pleasure which naturally results to a Man from being the first discoverer... this service would be insupportable... The world will hardly admit of an excuse for a man leaving a Coast unexplored he has once discover'd, if dangers are his excuse he is then charged with Timorousness... if on the other hand he boldly encounters all the dangers and obstacles he meets and is unfortunate enough not to succeed he is then charged with Temerity and want of Conduct.(Beaglehole, p. 380)

Cook's sense of this is not, as Sahlins argues, of prescriptive systems, that nothing is new "even when what happens is unprecedented."(Sahlins, p. xii) He feels keenly the phenomenal uniqueness of his experience as 'first discoverer,' whose sole pleasure resides in being first: the first person singular topographically and grammatically. However, the pleasure of singularity raises the question of the genre of narratives available for probable self-delivery, and of the conflict between first-hand accounts of hazards and the scrolled particulars preferred by the 'world,' represented by that hypothesised man, perfectly obedient to Admiralty orders, who is always prepared for the unprecedented situation and able to slot it into a credible narrative. Cook is so troubled by his intuition of the discreditable nature of reporting the pleasure of being first among the hazards of the limit, that he projects the guilt of story-telling upon his crew:

\footnotetext{
For such are the disposition of men in general in these Voyages that they are seldom content with the hardships and dangers which will naturally occur, but they must add others which hardly ever had existence but in their imaginations, by magnifying the most trifling accidents and Circumstances to the greatest hardships, and unsurmou[n]table dangers without the imidiate interposion of Providence, as if the whole Merit of the Voyage consisted in the dangers and hardships they underwent, or that real ones did not happen often enough to give the mind sufficient anxiety; thus posterity are taught to look upon these Voyages as hazardous to the highest degree. (Beaglehole, 1. 461)
}

Apart from his sense that the combination of the first person singular with the chances of a cruise in an unknown ocean cause the generic boundaries of truth and fiction to dissolve, it is hard to work out quite what Cook wants to say; for it seems that the only extravagance this imagined narrative will commit is to call dangers dangers and hardships hardships, magnifying accidents in the same tautologous fashion that Cook magnifies the first person. "I say ' $\mathrm{I}$ ', this singular ' $\mathrm{I}$ '... the Now is point to, this Now. 'Now'." [Hegel, Phenomenology, pp. 62-63].

At the barest side of chance is the first person at the limit, absorbed in an un-relative event, who simply proclaims his identity there: here on the boundary of world stand I, and I am I. At the most scrolled and canonical side of probability is a system of prediction based on the third person who demands or exemplifies the universal element within all human testimony - a system that discredits as monstrous all assertion and reports not foreseeable by virtue of a priori concepts or of common sense. If any negotiation is to occur between these two extremes, that is to say, if the first person is to acquire probability in the narration of hazards, it will occur by means of a rhetorical adjustment of particulars. For Cook this adjustment wickedly relies upon the magnification of particulars; for the French it was quite the opposite. 
They instituted a mode of travel-writing designed to preserve the first-person in a universalised form. In his influential Histoire des Navigations aux Terres Australes, Charles de Brosses assured his audience that, "Le navigateur parle presque toujours lui meme a la premier personne." But the voice will have been subtly adjusted, purged of inelegancies, repetitions and arid details such as dates, distances, anchorages, winds, currents and so forth, and be carefully arranged alongside reports from the same region. Although therefore "l'auteur des faits parl[e] lui-meme de sa proper action" he will acquire authority by passing, as it were, insensibly through the universalising mouth of his historian. ${ }^{19}$ Prevost goes even further, manufacturing out of several navigations a joint account that will constitute a system of geography as well as a corpus of narratives, aimed to represent "avec autant d'ordre que de plenitude, l'etat present de toutes les Nations." 20 Now it is clear that their priority is to render the singularities of the first person adventurer in a acceptable form precisely by ejecting details and circumstances that are too particular. A concern of equal importance with this of editing and shaping the raw data of the original journal into a universal form is that of not disturbing the reader. By getting rid of "petits details inutiles"(Prevost, p. v), the convenience of the reader is always consulted, who is by means of these abridgements saved from "intolerable ennui" (de Brosses, p. ix).

When Dalrymple, the arch-advocate of a great southern continent, defended the empiricist alternative preferred by the British, he was well aware that unprocessed accounts of singular events are liable to be greeted with intolerance. He confesses that his Historical Collection of Voyages (1770-71) "was as disagreeable to me in writing, as it will be to the reader in his perusal: I am not insensible that the undress and uncouth sound of a literal translation is enough to frighten all readers except for the very few who take up a book merely for information."(i.1) What Dalrymple is defending, specifically against the reader's interest, is the figure of autopsy which, according to Pagden's account of the Conquesta historians, preserves both the first person and the multifarious and intricate details that empower its narrative. "It is the appeal to the authority of the eye witness, to the privileged understanding which those present at an event have over all those who have only read or been told about it." And it consists in amplification. The aim of the narrator ought to be, as Jean de Lery puts it, "to leave nothing out, if that is possible." (Pagden, p. 51) Lemuel Gulliver provides a notorious fictional example, partly based on Dampier, whose commitment to observing "the true Nature and State of the Things described" has, he notices, met with public disapproval. "It has been objected against me by some, that my Accounts and Descriptions of Things are dry and jejeune, not filled with variety of pleasant Matter, to divert and gratify the Curious Reader." (ANew Voyage, 3, ii) Bougainville encountered the incredulity of his translator, J.-R. Forster because, he partly suspected, his "relation detaillee" was too heavily marked by "la vie errante and sauvage que je mene depuis douze ans. Ce n'est ni dans les forets du Canada, ni sur le sein des mers, que l'on se forme a l'art d'ecrire." 21 He is simply a seaman, "c'est a dire un meneur and un imbecille." (1, xi) Even though he defends an unedited account, Dalrymple suspects that without an editorial supplement, no eyewitness testimony will make much sense or be believed: "Perhaps, indeed, no single voyage can give authentic memorials for such a work [i.e. his translation], without filling up by a web of conjecture what is wanting in the original." 22 It is an effort to be faithful to these discontinuities in his original that John Hawkesworth owns of his compilation of voyages (including Cook's first). "It will probably be thought by many Readers, that I have related the nautical events too minutely." But, he adds, "minutely to relate these events was the great object of the work... for it is from little circumstances that the relation of great events derives its power over the mind." 23

The anticipation of readerly hostility to autopsy is not ill-founded. The Monthly Review recommended the account of Cook's second voyage, reassuring readers who expected nothing more than "an authentic, but dry and every returning detail of latitudes and longitudes, and of bearings, distances, and soundings" that they 'will here meet with much expected entertainment." 24 But the Critical Review reversed the judgement in respect of Hawkesworth's work. Although the authors have been "particularly explicit in the detail of all such remarks as served to delineate the maritime circumstances," it observed, this punctuality has not "prevented them from mixing their detail with trifling incidents or reflexions foreign to the subject." 25 George Forster, who offered an account of Cook's second voyage upon new principles of philosophical order, disparaged all previous narratives in these terms: "Facts were collected... and yet knowledge was not increased. [The public] received a 
confused heap of disjointed limbs, which no art could reunite into a whole; and the rage of hunting after facts soon rendered them incapable of forming and resolving a single proposition." 26 The Edinburgh Magazine said of Hawkesworth, "His work abounds with a multitude of frivolous particulars."

Cook's intuition of the dissolving barriers between a report of maritime exploration and a fiction is explicitly addressed by his ventriloquist, Hawkesworth. He compares his minutely detailed redaction of Cook's and Banks's journals to Richardson's Pamela, "the imaginary herione of a novel that is remarkable for the enumeration of particulars in themselves so trifling, that we almost wonder how they could occur to the author's mind."(Hawkesworth, pp. vi-vii) However, these are the particulars which, solely by virtue of their number, will command attention and belief, and exert their power over the reader's mind.

In fact, Hawkesworth revels in all the narrative liberties which have formed the outline of Cook's complaint against the improbability of the tales of his own crew. Clearly he is keen to multiply the circumstances of vicissitudes, "magnifying the most trifling accidents and Circumstances to the greatest hardships." He is eager also to deny the particular interposition of providence, arguing in his preface that it was not owing to God that the wind dropped after the Endeavour went aground on coral, but to sheer chance. "Either the subsiding of the wind was a mere natural event or not; if it was a natural event, providence is out of the question, at least we can with no more propriety say that providentially the wind ceased, than that providentially the sun rose in the morning."(Hawkesworth, 1, xxi) Hawkesworth could not have presented hazard in a more monstrous form. Nor was he in the least inclined to justify the violence of unrelative events by reference to larger narratives of imperial or civilising missions. When it came to firearms, a topic on which Lord Morton had expatiated in the most moving terms in Cook's Royal Society instructions, he says quite simply, "When the command to fire has been given, no man can restrain its excess, or prescribe its effect." (Hawkesworth 2, p. 122) It is an observation of peculiar pertinence to the muddle in Kealakekua Bay, where Cook's decision to fire provoked the violent reaction that cost him his life. "Every excess thus produced is also an inevitable evil," cautions Hawkesworth, but it is unavoidable.

And all this Hawkesworth chose to deliver in Cook's own voice, being convinced that, "a narrative in the first person, would, by bringing the Adventurer and the Reader nearer together, without the intervention of a stranger, more strongly excite an interest." He combines particularity with a first person narrative in order to insist on the unrelative, unprovidential and unenlightened nature of limit-events. If Cook thinks the exaggerations of his crew will result in dangers and hardships being reiterated as dangers and hardships, then the only solecism that will have been committed is the elaboration of the tautology that stands as index of the highest degree hazard or miracle of discovery. In effect, Hawkesworth does no more than expand the tautology around the testimony of the first discoverer: the man who, as Dalrymple puts it, has "done that which no one else ever did before, or can do after him."(Dalrymple, 1, p. xvii) His orientation of the stranger's first person to that of the first discoverer's is the presentation of inconceivable event as inconceivable event by means of minute relation, "for it is from little circumstances that the relation of great events derives its power over the mind." And what is the event? That "which no imagination could possibly conceive."(Hawkesworth, 2, p. 207) A coconut without a scroll.

Hawkesworth's plan is quite the opposite of de Brosses' and Prevost's in this respect. Instead of straining and shaping the original account through the universalising mouth of the invisible historian, he is determined to preserve its intractability. "A digest could not have been made of the whole, without invading the right or each navigator to appropriate the relation of what he had seen."(Hawkesworth, p. vi) By virtue of placing events within the pure ether of experience, where causes act as no more than a chimerical ornament to self-evidence, autoptic vividness is sustained in all its absolute discontinuity. In the voice of Cook, Hawkesworth declares, "The principle causes were such as necessarily resulted from our situation and circumstances, in conjunction with the infirmities of human nature."(Hawkesworth 2, p. 182) It is like Hume's explanation for the footprint; namely, that there was some cause adapted to it by whose means it was produced. It is an explanation that leaves the terror of the inexplicable intact. It is to say that events are known by the experience of 
them, that dangers are dangers, and that fear is fear. He will not use hindsight to transform the unforeseeable into predictability, or to blunt the edge of Cook's complaint. Like Oviedo before him, Hawkesworth finds in Job the only scripture apt for the work of delivering indistinguishable particulars: "Shall we receive good from the hand of God and shall we not receive evil?"(Hawkesworth 1, p. xix)

Hawkesworth's fidelity to the experience of unrelative events was not an achievement for which Cook was likely to be grateful, since it set in amber exactly those unscrolled moments in his career which he feared would attract charges of disobedience and mendacity. He wanted an 'I' like de Brosses' or like Adam Smith's impartial spectator that would legitimate his account with posterity by means of a narrative consistent with the commonsense of 'men in general.' Nor were Hawkesworth's readers better pleased. They hated his tedious devotion to the particular; they condemned him for his blasphemy and for the lusciousness of the sexual material; they despised his extenuation of violence, and Dalrymple even blamed him for the loss of the Great Southern Continent. For Cook, Hawkesworth was a godsend, embodying as he did all the unacceptable and opprobrious aspects of discovery. Six months after publishing his Account, Hawkesworth died of resentment and despair, complaining bitterly at the way he had been treated by the public. Six years before, Cook was to die contingently and unforeseeably in a setting framed by the presence and absence of minute particulars, Hawkesworth fell a victim to the narrative intransigence of the same sort of particularity. It was not worms as done them in (Sahlins is quite right about this), it was coconuts.

1 Jeremy Bentham, A Fragment on Government, ed. J.H. Burns and H.L.A. Hart (University of London: Athlone Press, 1977), p. 393.

2 G.W.F. Hegel, 'Phenomenology of Spirit, trans. A.V. Miller (Oxford: Oxford University Press, 1977), p. 66.

3 Anthony Pagden, European Encounters with the New World (New Haven: Yale University Press, 1993), p. 52.

4 Cited in J.C. Beaglehole, The Voyage of the Resolution and Discorery, 2 vols. (London: The Hakluyt Society, 1967), 1. 535-36.

5 George William Anderson, A Complete Collection of Voyages Round the World, 1768-80 (London: Alexander Haig, 1784), p. iii.

6 Marshall Sahlins, Islands of History (Chicago: University of Chicago Press, 1985), p.108.

7 Gananath Obeyesekere, The Apotheosis of Captain Cook (Princeton: Princeton University Press, 1992), p. 170.

8 The words are those of James Trevenen, Kalaimoku and William Ellis, cited in Gananath Obeyesekere, The Apotheosis of Captain Cook, p. 186, 145; and in Marshall Sahlins, Islands of History, p. 104.

9 William Dampier, A New Voyage Round the World in A Collection of Voyages, 4 vols (London: J. and J. Knapton, 1729), 3, iii.

10 John Harris, A Complete Collection of Voyages and Travels, 4 vols (London: T. Woodward et al., 1744), 1, 332.

11 On the question of circumstantial evidence and its relation to narrative and history in the eighteenth century,

see Alexander Welsh, Strong Representations (Baltimore: Johns Hopkins University Press, 1992), pp. .2-42.

12 Michel de Certeau, "Travel Narratives of the French to Brazil," Representations 33 (Winter, 1991): 223.

13 David Hume, Essays Moral, Political and Literary (London: World's Classics, 1903), pp. 528, 523.

14 David Hume, An Enquiry Concerning Human Understanding, ed. L.A. Selby-Bigge (Oxford: Clarendon Press, 1975), p. 144.

15 Henry St John, Lord Bolingbroke, Letters on the Study and the Use of History (London: A. Millar, 1652), p. 34.

16 The Voyage of the Resolution and the Adventure, ed. J.C. Beaglehole (Cambridge: Cambridge University Press and the Hakluyt Society, 1961), p..322.

17 Compare Oviedo: "Here he is wounded without a surgeon, sick without a doctor or medicines, hungry without food, thirsty without water, tired without beiong able to sleep, needy with nothing in which to dress himself, and with no shoes for his feet." Historia de las Indias, ed. Juan Perez de Tudela Bueso (Madrid, 1959), 2.304; cited in Pagden, Encounters, p. 66.

18 Robert K. Merton's rule, cited in Chrispher Herbert, Culture and Anomie: Ethnographic Imagination in the Nineteenth Century (Chicago: Chicago University Press, 1991), p. 69.

19 Charles de Brosses, Histoire des Navigations aux Terres Australes, 2 vols (Paris, 1756), 1.viii-ix.

20 Antoine-Francois Prevost, Histoire Generale des Voyages (Paris, 1746), 1.v.

21 Louis de Bougainville, Voyage autour du mond, 2 vols (Paris: Saillant et Nyon, 1772), 1, pp. .xiv, xxxvii, xxxix.

22 Alexander Dalrymple, An Historical Collection of Voyages and Discoveries in the South Pacific Ocean, 2 vols (London, 1770-71), 1, p. .x-xi.

23 John Hawkesworth, An Account of the Voyages and Discoveries in the Southern Hemisphere, 3 vols (London: W. Strahan and T. Cadell, 1773), 1, p. vi-vii.

24 The Monthly Review; or Literary Journal, vol. 57 (London: R. Griffiths, 1778), p. 18.

25 The Critical Review; or Annals of Literature (London: A. Hamilton, 1773), p. .242.

26 George Forster, A Voyage Round the World, 2 vols (London: B. White, 1777), 1, p. .xi. 